\title{
Survey of Bemisia tabaci (Gennadius) (Hemiptera: Aleyrodidae) biotypes in Brazil using RAPD markers
}

\author{
L.H.C. Lima, D. Návia, P.W. Inglis and M.R.V. de Oliveira
}

\begin{abstract}
In 1991, the poinsettia strain, silverleaf whitefly or B biotype of Bemisia tabaci was detected in Brazil. This variant is a far more serious agricultural pest than the previously prevalent non-B (BR) biotype. The correct identification of $B$. tabaci is problematic since it is highly polymorphic with extreme plasticity in key morphological characters that vary according to the host. RAPD-PCR was used to survey the $B$ biotype and other biotypes of $B$. tabaci in Brazil. Whiteflies were collected from cultivated plants and weeds from 57 different localities and on 27 distinct crops. RAPD analyses using two selected 10-mer primers reliably identified the BR biotype and the B biotype of $B$. tabaci and also differentiated other whitefly species. The presence of the B biotype was confirmed in 20 Brazilian states. The BR and B biotypes of $B$. tabaci were found to coexist in the whitefly populations of three different localities: Jaboticabal, SP; Rondonópolis and Cuiabá, MT, and Goiânia, GO.
\end{abstract}

\section{INTRODUCTION}

In the last two decades, the sweetpotato whitefly, Bemisia tabaci (Gennadius) (Hemiptera: Aleyrodidae), has become one of the most important pests of agricultural crops worldwide. B. tabaci is a vector of numerous plant viruses and also reduces crop production by direct feeding. Infestations of $B$. tabaci, associated with phytotoxic symptoms of squash silverleaf in Cucurbita spp., uneven ripening of tomato and white stem disorder in Brassica spp., were first described in the US. Similar phytotoxic-like disorders are now widespread throughout cropping systems in many countries (Costa et al., 1993; Brown et al., 1995; Hilje, 1996), including Brazil.

The heavy use of pesticides, intensive agricultural production, overlapping crop seasons and an insect pest species with the biotic potential to exploit a wide resource base within a permissive environment may have contributed to the aggregation of strains or races which are morphologically indistinguishable but genetically different from each other (Wool et al., 1993; Toscano et al., 1998). Among the races or biotypes of $B$. tabaci, the B biotype has caused tremendous losses worldwide. The B biotype has a broader host range, and a higher honeydew egg production than the less damaging A biotype (Bethke et al., 1991; Costa and Brown, 1991).

B. tabaci was first identified in Brazil in 1928 on $\mathrm{Eu}$ phorbia pulcherrima in Bahia State (Bondar, 1928). From the Northeast, the insect spread to other regions of the country where outbreaks were previously occasional and problems were caused largely due to its properties as a vector. Bean production was affected by the bean golden mosaic virus in many regions and tomato and soybean crops were also occasionally infected with geminiviruses transmitted by B. tabaci (Ribeiro et al., 1998; Ferreira et al., 1999).

In the early 1990 's, a heavy infestation of $B$. tabaci on important crops and wild plants was detected in São Paulo State, where there is extensive international trade in ornamental plants. The changes in the behavior of $B$. tabaci populations were similar to those observed for the emergence of the B biotype in other countries (Lourenção and Nagai, 1994). Since its arrival, substantial losses due to $B$. tabaci have been reported by 21 out of 27 Brazilian states.

Important crops such as melons, watermelons, cotton, bean, tomato and cucumber have been damaged. In many areas, losses of 20 to $100 \%$ have been reported with the estimates being close to US $\$ 1$ billion, although a precise monetary loss has not been calculated (Ferreira and Avidos, 1998).

Molecular analysis has been used to identify and characterize whitefly populations. Esterase pattern analysis was applied to population studies of B. tabaci, which demonstrated the association of the B biotype with silverleaf symptoms (Costa and Brown, 1991). Electrophoretic analysis of esterase isoenzymes has also been used to determine the genetic variation between individuals of the whitefly species, Trialeurodes vaporariorum (Westwood) and B. tabaci (Liu et al., 1992). This approach enabled the differentiation between species and distinguished whitefly males and females (Oliveira and Lima, 1997).

Random amplified polymorphic DNA polymerase chain reaction (RADP-PCR) is a relatively simple, inexpensive and rapid technique, revealing polymorphisms which are useful as genetic and taxonomic markers (Welsh and McClelland, 1990). RAPD has been applied to studies 
of insects (Haymer, 1994) and to differentiate whiteflies, including the identification of the $\mathrm{A}$ and $\mathrm{B}$ biotypes of $B$. tabaci (Gawel and Bartlett, 1993).

\section{MATERIAL AND METHODS}

Adult whiteflies were collected from host plants and fields using a hand-held aspirator and preserved immediately in 100\% ethanol for later processing. A total of 61 samples, each of approximately 100 insects, were collected from 53 localities in 15 states and on 27 distinct crops. All insects used in this study were from infestations identified as $B$. tabaci based on the morphology of the pupal stage. Reference colonies of $B$ biotype adults originating from California, USA, and a non-B biotype (biotype A) originating from Arizona, USA (Perring et al., 1993), were used as standard.

DNA was extracted from 10 individual insects of each sample, according to a standard protocol (Barro and Driver, 1997) with several modifications. Individual female whiteflies were homogenized in $56 \mu$ lysis buffer $(10 \mathrm{mM}$ Tris$\mathrm{HCl}, \mathrm{pH} 8.0,1 \mathrm{mM}$ EDTA, $0.30 \%$ Triton X-100, $60 \mu \mathrm{g} / \mathrm{ml}$ proteinase $\mathrm{K}$ ) using a $1.5-\mathrm{ml}$ microcentrifuge tube and

Table I - Nucleotide sequence of RAPD primers.

\begin{tabular}{|cl|}
\hline Primer name & Sequence (5' ${ }^{\prime}{ }^{\prime}$ ') \\
\hline OPA-02 & TGCCGAGCTG \\
OPA-04 & AATCGGGCTG \\
OPA-05 & AGGGGTCTTG \\
OPA-10 & GTGATCGCAG \\
OPA-11 & CAATCGCCGT \\
OPA-13 & CAGCACCCAC \\
OPA-15 & TTCCGAACCC \\
OPA-20 & GTTGCGATCC \\
OPR-07 & ACTGGCCTGA \\
OPE-13 & CCCGATTCGG \\
\hline
\end{tabular}

micropestle. The homogenate was incubated at $65^{\circ} \mathrm{C}$ for $15 \mathrm{~min}$ and boiled for $6 \mathrm{~min}$ to inactivate proteinase $\mathrm{K}$. Processed samples were stored at $-20^{\circ} \mathrm{C}$.

The two 10mer primers (Operon Technologies Inc., Alameda, CA, USA) used for RAPD-PCR are shown in Table I. PCR was performed in a 30- $\mu$ l reaction mix containing $6.0 \mathrm{mM}$ Tris-HCl, $\mathrm{pH} 8.8,1.5 \mathrm{mM} \mathrm{MgCl}, 0.2 \mathrm{mM}$ dNTPs, $0.4 \mu \mathrm{M}$ primer, $2.5 \mathrm{U}$ of Taq DNA polymerase and 10-15 ng DNA. Mineral oil $(25 \mu \mathrm{l})$ was added on the top of the reaction mix. Samples were amplified using a PTC-100 thermocycler (MJ Research) with the following program: one cycle of $3 \mathrm{~min}$ at $94^{\circ} \mathrm{C}$ followed by 45 cycles of $1 \mathrm{~min}$ at $93^{\circ} \mathrm{C}, 1 \mathrm{~min}$ at $35^{\circ} \mathrm{C}$ and $2 \mathrm{~min}$ at $72^{\circ} \mathrm{C}$, followed by a final cycle of $5 \mathrm{~min}$ at $72^{\circ} \mathrm{C}$. PCR products were separated by electrophoresis on $1.5 \%$ agarose gels, run at $5 \mathrm{~V} / \mathrm{cm}$ for $3 \mathrm{~h}$ in 0.5X TBE buffer. A 100-bp ladder (Amersham Pharmacia Biotech) was included on each gel as molecular weight marker. DNA bands were visualized under UV light after staining with a $0.5 \mu \mathrm{g} / \mathrm{ml}$ ethidium bromide solution. Gels were documented using the Eagle-Eye II System (Stratagene). A negative control without DNA was included in all reaction sets.

\section{RESULTS AND DISCUSSION}

RAPD-PCR was used to identify whiteflies from 61 sampling sites originating from different Brazilian localities and crops. Representative samples of B. tabaci biotype A, collected from wild populations in Arizona, USA, and biotype $\mathrm{B}$ colonies from California, USA, were included in each reaction set as identification control. Brazilian isolates with profiles resembling biotype A are subsequently referred to as biotype BR. For each site or crop, PCR was conducted with the DNA of 10 individual insects for each RAPD primer (see Figure 1). All 10 primers screened in this study (Table I) produced RAPD patterns that clearly

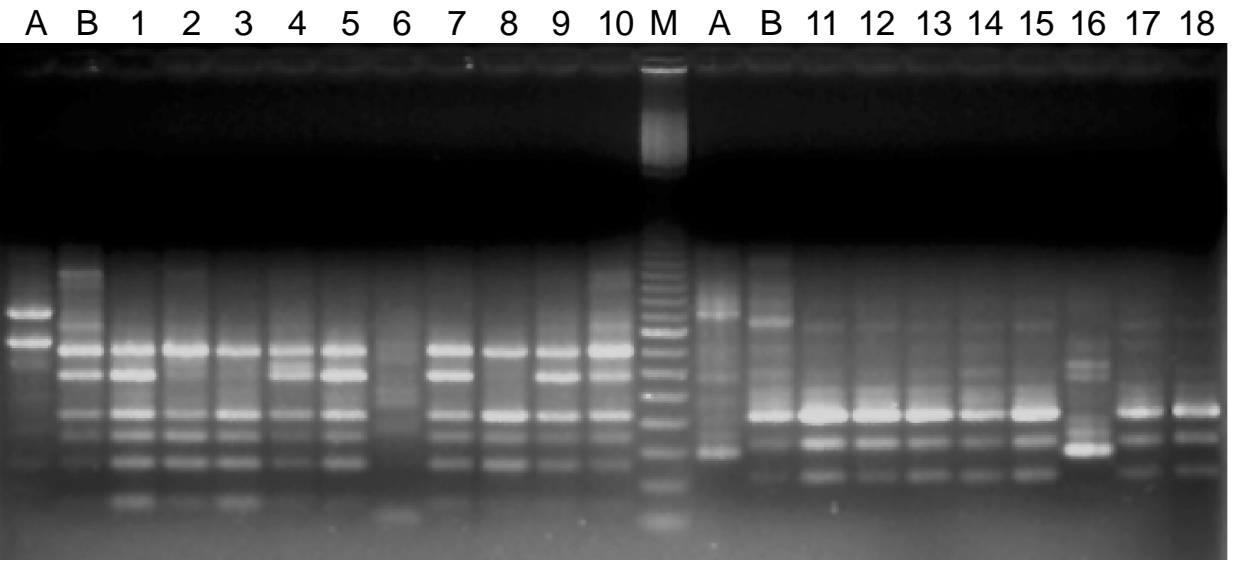

Figure 1 - A representative RAPD reaction set for the differentiation of whitefly biotypes. M: 100-bp DNA ladder (Amersham Pharmacia Biotech); samples on the left of the marker were amplified using primer OPA-04 and samples on the right of the marker using OPA-10. Lanes 1-6: Individual whiteflies from cabbage and lanes 7-10: individual whiteflies from melon. Lanes 11-14: Individual whiteflies from cabbage and lanes 15-18: individual whiteflies from melon. Standard biotypes (biotype A, Arizona, USA, and biotype B, California, USA) used for identification are indicated by the letters A and B, respectively. 
Table 2 - Biotype identification using RAPD markers of Bemisia tabaci sampled from different crops and localities in Brazil.

\begin{tabular}{|c|c|c|}
\hline Crop & Locality & $\begin{array}{l}\text { Identification } \\
\text { (biotype) }\end{array}$ \\
\hline 01 - melon & Arizona - USA & A-type (= BR) \\
\hline 02 - melon & California - USA & B-type \\
\hline 03 - bean & Goiânia-GO & BR-type \\
\hline 04 - melon & Brasília - DF & B-type \\
\hline 05 - bean, eggplant & Jaboticabal - SP & $\mathrm{B}$ \\
\hline 06 - tomato, cabbage & Lavras - MG & B \\
\hline 07 - squash & Mançuba - BA & $\mathrm{B}$ \\
\hline 08 - cotton & Campina Grande - PB & $\mathrm{B}$ \\
\hline 09 - cotton & Guanambi - BA & $\mathrm{B}$ \\
\hline 10 - okra, various weeds, bean, soybean & Rondonópolis - MT & $\mathrm{BR}$ \\
\hline 11 - cucumber & Guaiuba-CE & $\mathrm{B}$ \\
\hline 12 - watermelon & Itaberaba - BA & $\mathrm{B}$ \\
\hline 13 - tomato, squash, weeds, peanut & Petrolina - PE & $\mathrm{B}$ \\
\hline 14 - cabbage, sweet pepper & Itaiçaba - CE & B \\
\hline 15 - melon, watermelon, tomato & Aracati - CE & B \\
\hline 16 - cabbage & Tianguá - CE & B \\
\hline 17 - soybean, cotton & Miguelópolis - SP & $\mathrm{B}$ \\
\hline 18 - tomato & Pacoti - CE & $\mathrm{B}$ \\
\hline 19 - squash & Vassouras - RJ & $\mathrm{B}$ \\
\hline 20 - melon, soybean & Boa Vista - RR & $\mathrm{B}$ \\
\hline 21 - okra, watermelon, tomato, squash & Goiânia - GO & B \\
\hline 22 - bean and cucumber & Goiânia - GO & $\mathrm{BR}$ \\
\hline 23 - lettuce, tomato, cabbage & Goianira - GO & $\mathrm{B}$ \\
\hline 24 - bean & Limoeiro do Norte - CE & $\mathrm{BR}$ \\
\hline 25 - soybean & Piracicaba - SP & $\mathrm{B}$ \\
\hline 26 - soybean & Pedra Preta - MT & $\mathrm{BR}$ \\
\hline 27 - tomato & Uberlândia - MG & $\mathrm{B}$ \\
\hline 28 - melon & Russas - CE & $\mathrm{B}$ \\
\hline 29 - squash & Tabuleiro do Norte - CE & $\mathrm{B}$ \\
\hline 30 - broccoli, okra, gherkin & Taiobeiras - MG & $\mathrm{B}$ \\
\hline 31 - broccoli, cabbage, carrot & Salinas - MG & B \\
\hline 32 - cucumber, eggplant, sweet pepper & Planura - MG & B \\
\hline 33 - cauliflower, cabbage, tomato & Teófilo Otoni - MG & B \\
\hline 34 - cotton & Janaúba - MG & B \\
\hline 35 - soybean & Viçosa - MG & $\mathrm{B}$ \\
\hline 36 - soybean & Carolina - MA & $\mathrm{B}$ \\
\hline 37 - soybean & Riachão - MA & $\mathrm{B}$ \\
\hline 38 - soybean & St. Antônio de Goiás - GO & $\mathrm{B}$ \\
\hline 39 - lettuce, broccoli, cabbage & Palmas - TO & $\mathrm{B}$ \\
\hline 40 - cabbage & Mogi Mirim - SP & $\mathrm{B}$ \\
\hline 41 - grape & Campinas - SP & $\mathrm{B}$ \\
\hline 42 - eggplant & Espírito Santo do Pinhal - SP & $\mathrm{B}$ \\
\hline 43 - cabbage & Campos Goytacazes - RJ & $7 \mathrm{~B}+3 \mathrm{BR}$ \\
\hline 44- melon, watermelon & Mossoró - RN & B \\
\hline 45 - tomato & Teresina - PI & $\mathrm{B}$ \\
\hline 46 - watermelon & São João - PI & $\mathrm{B}$ \\
\hline 47 - eggplant, cucumber, bitter eggplant & Cuiabá - MT & $8 \mathrm{~B}+2 \mathrm{BR}$ \\
\hline 48 - weed, leguminosae, forage & Campo Grande - MS & $\mathrm{B}$ \\
\hline 49 - cabbage, squash & Vitória-ES & $\mathrm{B}$ \\
\hline 50 - squash, cabbage, soybean, tomato, cauliflower, broccoli & Brasília - DF & $\mathrm{B}$ \\
\hline 51 - tomato, watermelon & Paulo Afonso - BA & $\mathrm{B}$ \\
\hline 52 - squash, watermelon, bean & Pão-de-açúcar - AL & $\mathrm{B}$ \\
\hline 53 - squash & Delmiro Gouveia - AL & $\mathrm{B}$ \\
\hline 54 - melon, squash & Iaçu - BA & $\mathrm{B}$ \\
\hline 55 - cotton & Display Plot/Embrapa - DF & $\mathrm{BR}$ \\
\hline $56 \mathrm{a}$ - cotton, soybean & Display Plot / Embrapa - DF & BR (initial) \\
\hline $56 \mathrm{~b}$ - cotton, soybean & Display Plot / Embrapa - DF & B (week 2) \\
\hline 57 - bean & Display Plot / Embrapa - DF & $\mathrm{B}$ \\
\hline 58 - tomato & Recife-PE & B \\
\hline 59 - cotton & Recife-PE & B \\
\hline 60 - cabbage & Recife-PE & B \\
\hline 61 - tomato & Recife - PE & B \\
\hline 62 - cucumber & Vilhena-RO & B \\
\hline
\end{tabular}


Table II - Continued

\begin{tabular}{|lll|}
\hline Crop & Locality & $\begin{array}{l}\text { Identification } \\
\text { (biotype) }\end{array}$ \\
\hline 63 - tomato & Santa Cruz do Sul - RS & B \\
64 - melon & Baraúna - RN & B \\
65 - tomato & Tibau - RN & B \\
66 - melon & Assu - RN & B \\
67 - tomato & Trindade - GO & B \\
68 - tomato & Tocantins - MG & B \\
69 - cotton & Lagoa - PB & B \\
70 - bean & São João do Jaguaribe - CE & B \\
71 - tomato, melon & Quixeré - CE & B \\
72 - tangerine & Bonfim - MG & B \\
73 - soybean & Balsas - MA & B \\
74 - cabbage & Caruaru - PE & B \\
75 - tomato & Vitória - PE & B \\
76 - tomato & Sapucarana - PE & B \\
77 - bean & Buriti de Goiás - GO & BR \\
78 - weeds & Nilo Coelho - PE & B \\
79 - weeds & Feira de Santana - BA & B \\
\hline
\end{tabular}

distinguished biotype B individuals from non-B individuals (data not shown). The average number of RAPD bands produced in a single reaction was 7.8 per primer and ranged from 300 to $600 \mathrm{bp}$. Patterns produced within the 10 replicate samples were highly homogenous; however, the relative intensity of some bands was occasionally variable. The produced profiles usually resembled those of the corresponding standard biotypes originating from the US. In some reaction sets we also used the native biotypes from Brazil as control, which induced silverleaf symptoms on squash, and two other whitefly species: T. vaporariorum and Aleurothrixus floccosus (Maskell). The RAPD profiles of the last two species were always highly distinct from the $B$. tabaci profiles.

Primers OPA-04, OPA-10 and OPA-13 gave the clearest and most unambiguous DNA profiles and were used for most whitefly identifications shown in Table II. These primers also reliably separated $B$. tabaci biotypes from $T$. vaporariorum and $A$. floccosus. No assessed crop was found to be exclusively infested by the BR biotype of $B$. tabaci. The survey rather demonstrated the dominance and broad host range of the $\mathrm{B}$ biotype in Brazil.

Figure 2 illustrates the distribution of the BR and B biotypes among the different states of Brazil. Investigations after the first detection of the B biotypes in 1993 suggested that the insect was first introduced in 1991 via poinsettias imported from California to Holambra, São Paulo (Lourenção and Nagai, 1994). Our survey shows that this biotype is now well established and widespread in the northeast, east and midwest of Brazil. However, we did not detect the $\mathrm{B}$ biotype in the southern- and westernmost Brazilian states, due to a potential climatic influence on the spread of two B. tabaci biotypes. The occurrence of both $\mathrm{BR}$ and B biotypes was confirmed in the States of Mato Grosso, Goiás and Rio de Janeiro. We also found both biotypes in the Federal District, at Embrapa (display plot), where a second sampling was made two weeks after the first. B. tabaci biotype BR was exclusively found in the

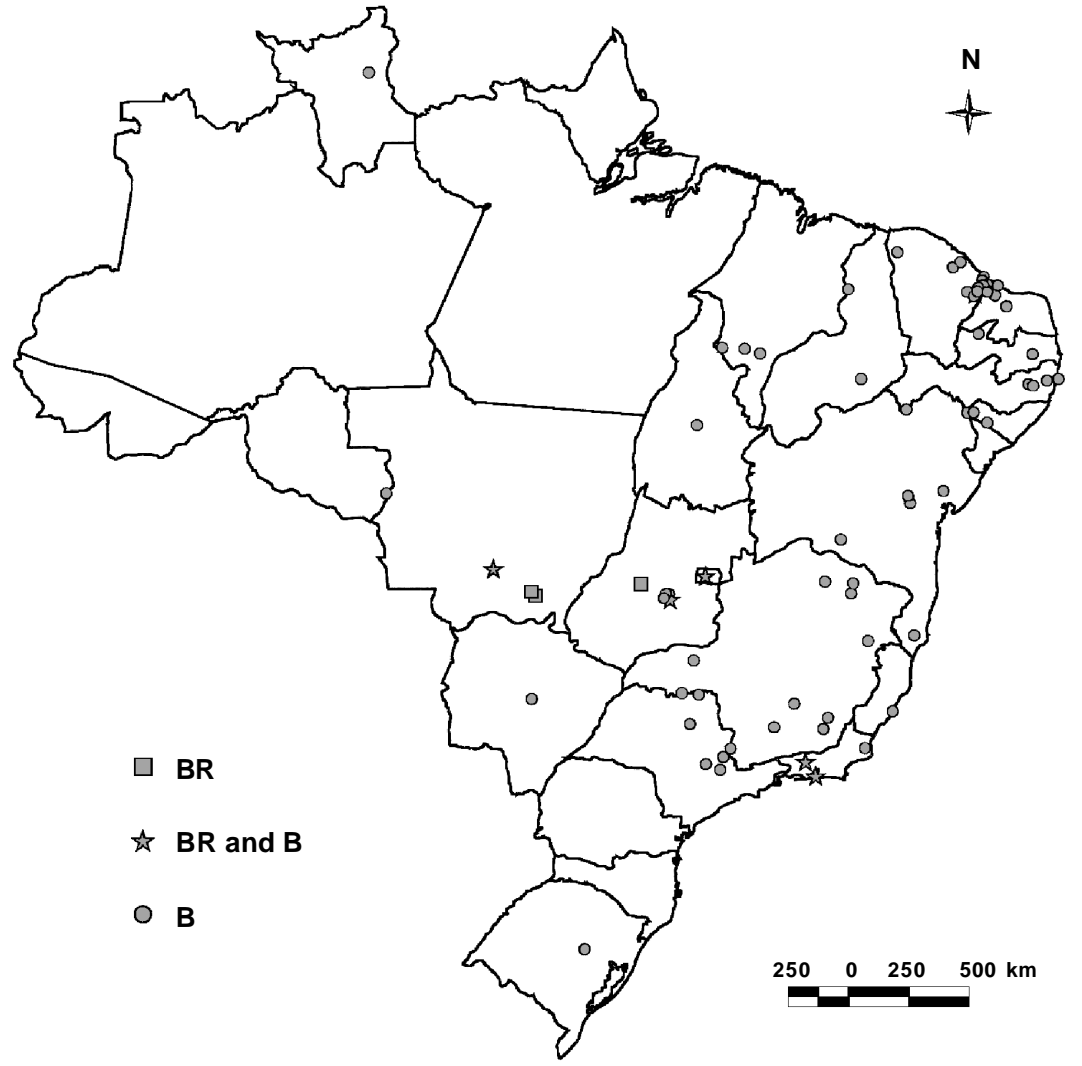

Figure 2 - Distribution of B. tabaci collected in Brazil and identified by RAPD markers. 
first sample. After two weeks, however, the original population appeared to have been replaced by the B biotype, illustrating the competitive advantage of this insect (Costa and Brown, 1991).

We found the use of RAPD-PCR to identify whiteflies to be relatively inexpensive (approximately US\$3.00/ specimen), requiring just 30 min for sample preparation and $10 \mathrm{~h}$ for RAPD analysis. The technique also has the advantage that alcohol can be used to preserve the insects, avoiding the need to keep samples alive or frozen. Effective monitoring of the spread and establishment of B. tabaci in Brazil and the ability to reliably distinguish non-B biotypes from the more important $B$ biotype of this pest will assist in the forecasting of potential losses and improve the prospects for adoption of appropriate management strategies.

\section{ACKNOWLEDGMENTS}

We are grateful to Dr. Odilson Luiz Ribeiro e Silva, Coordinator of Plant Protection, Department of Plant Inspection and Protection, Ministry of Agriculture and Food Supply.

\section{RESUMO}

Em 1991, um novo biótipo de Bemisia tabaci denominado de raça $\mathrm{B}$, mosca branca da poinsétia ou mosca da folha prateada foi detectado no Brasil. Esta praga trouxe muitos prejuízos e danos à agricultura nacional, por ser mais agressiva do que a existente anteriormente, conhecida como B. tabaci ou $B$. tabaci biótipo BR (não B). A relação taxonômica entre $B$. tabaci e $B$. tabaci biótipo $\mathrm{B}$ não é clara e não existem evidências morfológicas consistentes que possam distinguir esses dois biótipos. RAPD-PCR tem sido utilizada para identificação de biótipos presentes nas populações, utilizando-se, como padrões de referência, adultos de $B e$ misia tabaci das raças A e B provenientes dos Estados Unidos. As coletas de mosca branca foram feitas em 27 culturas e plantas daninhas em 57 localidades do país. As populações foram então analisadas, observando-se que a população predominante em 20 estados brasileiros é de $B$. tabaci biótipo B. Os biótipos BR e B foram encontrados coabitando a mesma região, em três diferentes localidades: Jaboticabal, SP; Rondonópolis e Cuiabá, MT e Goiânia, GO.

\section{REFERENCES}

Barro, P.J. and Driver, F. (1997). Use of RAPD PCR to distinguish the B biotype from other biotypes of Bemisia tabaci (Gennadius) (Hemiptera: Aleyrodidae). Aust. J. Entomol. 36: 149-152.

Bethke, J.A., Paine, T.D. and Nuessly, G.S. (1991). Comparative biology, morphometrics, and development of two populations of Bemisia tabaci
(Homoptera: Aleyrodidae) on cotton and poinsettia. Ann. Entomol. Soc. Am. 84: 407-411.

Bondar, G. (1928). Aleyrodideos do Brasil. Bolm. Lab. Path. Veg. Est. Bahia $5: 1-37$.

Black, W.C., DuTeau, N.M., Puterka, G.J., Nechols, J.R. and Pettorini, J.M. (1992). Use of the random amplified polymorphic DNA polymerase chain reaction (RAPD PCR) to detect DNA polymorphisms in aphids. Bull. Ent. Res. 82: 151-159.

Brown, J.K., Frohlich, D.R. and Rosell, R.C. (1995). The sweet potato or silverleaf whiteflies: biotypes of Bemisia tabaci or a species complex? Ann. Rev. Entomol. 40: 511-534.

Costa, H.S. and Brown, J.K. (1991). Variation in biological characteristics and esterase patterns among populations of Bemisia tabaci, and the association of one population with silverleaf symptom induction. Entomol. Exp. Appl. 61:211-219.

Costa, H.S., Johnson, M.W., Ullman, D.E., Omer, A.D. and Tabashnik, B.E. (1993). Sweetpotato whitefly (Homoptera: Aleyrodidae) analysis of biotypes and distribution in Hawaii. Environ. Ent. 22: 16-20.

Ferreira, L.T. and Avidos, M.F.D. (1998). Mosca Branca - Presença indesejável no Brasil. Rev. Bras. Biotecnol. Ciên. Desenvol. 4: 22-26.

Ferreira, P.T.O., Bezerra, I.C.. Villas Bôas, G.L., Ribeiro, S.G. and Giordano, L.B. (1999). Avaliação de fontes de resistência a isolado de geminivírus com genoma bipartido transmitido por Bemisia argentifolii em Lycopersicon spp. Rev. Soc. Bras. Fitopatol. 24: 131-135.

Gawel, N.J. and Bartlett, A.C. (1993). Characterization of differences between whiteflies using RAPD-PCR. Insect Mol. Biol. 2: 33-38.

Haymer, D.S. (1994). Arbitrary (RAPD) primer sequences used in insect studies. Insect Mol. Biol. 3: 191-194.

Hilje, L. (1996). Introdução. In: Metodologias para el Estudio e Manejo de Moscas Blancas y Geminivirus (Hilje, L., ed.). CATIE. Unidad de Fitoproteción, Materiales de enseñanza/CATIE No. 37, Turrialba, C.R., pp. 150.

Liu, H.Y., Cohen, S. and Duffus, J.E. (1992). The use of isoenzyme patterns to distinguish sweetpotato whitefly biotypes. Phytoparasitica 20: $187-194$

Lourenção, A.L. and Nagai, H. (1994). Surtos populacionais de Bemisia tabaci no Estado de São Paulo. Bragantia 53: 53-59.

Oliveira, M.R.V. and Lima, L.H.C. (1997). Padrões isoenzimáticos de Trialeurodes vaporariorum e de Bemisia tabaci (Homoptera: Aleyrodidae). Pesqui. Agropecu. Bras. 32: 683-687.

Perring, T.M., Cooper, A.D., Rodriguez, R.J., Farrar, C.A. and Bellows, T.S.J. (1993). Identification of a whitefly species by genomic and behavioral studies. Science 259: 74-77.

Ribeiro, S.G., Ávila, A.C., Bezerra, I.C., Fernandes, J.J., Faria, J.C., Lima, M.F., Gilbertson, R.L., Maciel-Zambolim, E. and Zerbini, F.M. (1998). Widespread occurrence of tomato geminiviruses in Brazil, associated with the new biotype of the whitefly vector. Plant Dis. 82: 830-834.

Toscano, N.C., Castle, S.J., Henneberry, T.J. and Prabhaker, N. (1998). Invasions by Bemisia and its explotation of agricultural systems. In: International Workshop on Bemisia and Geminivirus, San Juan, Puerto Rico, 7-12 July 1998, pp. 6.

Welsh, J. and McClelland, M. (1990). Fingerprinting genomes using PCR with arbitrary primers. Nucleic Acids Res. 18: 7213-7218.

Wool, D., Gerling, D., Bellotti, A.C. and Morales, F.J. (1993). Esterase electrophoretic variation in Bemisia tabaci (Gennadius) (Hem., Aleyrodidae) among host plants and localities in Israel. J. Appl. Entomol. 115: 185-196.

(Received August 8, 2000) 
